\title{
President Clinton's radio address on child passenger safety
}

Today [15 February 1997] I'm pleased to announce a major new step in our efforts to protect America's children - a universal system for attaching child safety seats in cars. This system, developed by a blue ribbon commission of industry and consumer groups, will make safety seats easier to install and more secure on the road. It will save young lives.

In my State of the Union address, I issued a call to action to all Americans to prepare our people for the 21 st century. Building strong families is central to that mission. That's why we must do all that we can to help parents do all that they can to live up to one of the greatest responsibilities anyone can have - to care for a child.

Parents are always on the lookout to make sure their children are safe. That's especially true when you get in the car. Thousands of children are killed in car accidents every year; tens of thousands more are injured. Even though America's cars and roads are the safest in the world, we must make them safer. That's why today - the final day of National Child Passenger Safety Week-I'd like to talk with you about the steps we're taking to save more lives on the road.

First, we will continue to stress the fundamental rules of safety: seat belts, safety seats for small children, children 12 and under buckled up and in the back seat. Last month, I instructed the outgoing Transportation Secretary, Federico Pena, to develop a plan to get more Americans to wear seat belts. I'm delighted to be joined today by our new Transportation Secretary, Rodney Slater, who came to us from the Federal Highway Administration. He knows a lot about this issue and he will present that plan to me in March. When he does, I will be ready to review it and act on it. We must also continue to support law enforcement in its effort to increase compliance with safety laws.

Second, we have taken action to make it clear that, on America's roads, there is no room for alcohol or drugs. We fought to make it illegal for all young people under 21 to drive with any alcohol in their blood, and 34 states now have these zero tolerance laws. We're also developing a plan to make teens pass a drug test as a condition of getting a driver's license.

Third, we've worked to make airbags, one of our most important safety tools, safer for children. All cars and safety seats now come with warning labels to remind drivers to keep children in the back seat. Plans are underway to permit manufacturers to install less powerful airbags and to phase in a new generation of 'smart' airbags. Airbags have saved a lot of lives. With these improvements, they'll save even more.

And today, we're taking a fourth step - we will make child safety seats safer. These seats are the most effective safety device to protect very young children. In car crashes, they reduce the risk of death or serious injury to infants by $70 \%$. The cut the fatality and injury rate for children aged 1 to 4 in half. But while all 50 states have car seat laws, studies show that $40 \%$ of the time young children do not even ride in safety seats; and even when they are placed in child safety seats, $80 \%$ of the time children are either not fully secured or the car seats are not propertly attached.

The fact is, despite parents' best efforts, car seats are hard to install. Not all 100 models of car seats fit in all 900 models of passenger cars. And even when they do, it's no simple task to put them in place. Seat belts are not designed primarily to hold child safety seats. Anyone who's wrestled with a car seat knows what I'm talking about. Thousands of frustrated parents have called our Transportation Department hotline with questions about how to use car seats properly.

Parents are not alone in their concerns automobile and car seat makers, consumer organizations, the medical community all have felt there was too much confusion surrounding child seat safety. In response to this problem, my administration convened a blue ribbon panel, with representatives from all these groups, to find ways to make it easier for parents to protect their children with safe, secure car seats.

Today, I am pleased that we are acting on the panel's number one proposal - a universal system for attaching car safety seats. Under a Transportation Department plan, every car safety seat would have two standard buckles at its base. Every car would be equipped with standard latches in the back seat designed specifically to fasten to these buckles. There would also be universal attachments to secure the top of the safety seat to the car's interior, so car seats would be locked in from top to bottom. This plan will go out for public comment next week. If approved, the new safety system could be on the market by 1999 .

A car seat can protect a child from the violence of the worst crashes. So today, we are acting to solve a problem that's been around for too long - we're taking steps to make sure that your child's car seat will stay put in your car every time. With this plan, we're moving closer to the day when safe, well attached car seats will be the rule of the road.

Together, these efforts represent a new spirit 
of cooperation in America - with industry and government working with the American people to support our families as they seek to make life safer and better for our children.

\section{Commentary}

Each year in the United States, almost 300 children in child safety seats are killed in motor vehicle crashes. Some of these fatalities can be attributed to crash severity but child seat misuse also plays an important role. In a recent National Highway Traffic Safety Administration (NHTSA) sponsored observational study of child seat usage patterns, approximately $80 \%$ of people made at least one significant error in installing the seats. NHTSA estimates that effectiveness of child safety seats is reduced from $71 \%$ to an actual $59 \%$ due to misuse.

Misuse results from limitations imposed by vehicle designs and ambiguous instructions regarding optimal usage of child seats. Although child seat designs are generally optimised for installation with lap belts, current vehicles have a variety of belt systems that lock by several mechanisms. Some require locking clips to impede movement of the belt or child seat during a crash while others, such as automatic seat belts, may not be compatible with a child seat at all. In addition, some vehicles have seat belt anchorages forward of the seat bight (the intersection of the seat cushion with the seat back) in order to better distribute crash loads low across the pelvis of an adult occupant. Child seats attached to these forward anchorage positions experience excessive movement during a crash which can result in a greater likelihood of head impact.

In 1990, the International Standards Organisation (ISO) convened a working group to address child restraint issues. They developed the 'ISOFIX' universal child seat anchorage system. This four point rigid attachment system includes two metal struts with 'jaws' on their ends that protrude from the lower back of the child seat and snap on to round bars installed by the vehicle manufacturer just below the seat bight. The other two jaws are at the bottom front of the child restraint. They connect to bars below the vehicle seat cushion.

Several groups have modified this system. The Canadian modification, the CANFIX/ CAUSFIX system, incorporates the two rigid lower back attachments with a top tether. The most recent design, the 'UCRA' (uniform child restraint anchorage), semirigid attachment system proposed by General Motors Corporation, consists of a top tether and two lower rigid or semirigid anchorages. This lower anchorage design would be equipped with additional latchplates installed by the vehicle manufacturer that would attach to buckles on the child seat. The ISOFIX has been redesigned to include a top tether and two lower rigid or semirigid anchorages (a hybrid system).

Much discussion has occurred in the inter- national community regarding the merits of each of these and other systems. User clinics, sled tests, and economic analyses were performed with differing results. The rigid anchors are preferred by the majority of the IS $\overline{\widehat{\theta}}$ Working Group members, in part because the rigid system has the potential to provide improved side impact protection.

Considerable disagreement continues $\mathrm{re}$ garding the need for top tethers, a topic thes has long been the subject of debate due t⿳亠幺幺 anticipated non-use. The Australian experi ence shows that high top tether usage rate (>99\%) can be achieved. The Australiaf proposal includes simple electrical or mechan ical sensors that visually warn the user if alf three attachment points, including the top tether, are not secure.

One further controversy concerns the uns versality of the anchorages. A flat latchplation system is favoured by some Americans, versus the $6 \mathrm{~mm}$ round bar attachment systems proposed by the Working Group.

The US President's radio address describes the NHTSA proposed rulemaking that will require the UCRA system (or a hybrid systerf with UCRA attachments) to be installed in alN vehicles and on all child safety seats by the years 1999. While the rigid and semirigid systems ars all far superior to what exists currently - a large determinant in the United States' decision to accept the UCRA, semirigid system was $\cos \mathbb{Q}$ Vehicle manufacturers claim that the UCR $\overrightarrow{0}$ system will add less than $\$ 20$ to the cost of $\bar{z}$ child seat whereas they say the rigid anchorage systems may double the cost. Others believe these estimates are grossly inflated. Other. issues claimed to favour the UCRA system are better potential for use in aircraft, near tern availability, and ease of retrofit.

Regardless of the controversies that continuo to exist, I believe that NHTSA's propose rulemaking is a great first step in enhancing the protection of children in motor vehicleș. The simple UCRA design will lessen confusio 8 and frustration surrounding child seat installa tion, thereby reducing misuse/non-use. More importantly, this proposed rulemaking mays force the international community to take united stand in favour of this or another system It is hoped that the final rulemaking adopted by NHTSA will further the goal of univers harmonisation of child restraint anchorages. Future work must focus on improving the protection of children in side impacts and of improving protection of the over 40 pound oldes child. Finally, no technology works perfectly in the real world and the need for continued education and evaluation cannot be ignored.

Congratulations President Clinton for 'snappy' address!

FLAURA KOPLIN WINSTO尺̊ Director, Trauma Lin Children's Hospital of Philadelph and the University of Pennsylvanis. 34th Street and Civic Center Blvd, Philadelphia, PA 19104, USA

For more details regarding the rulemaking, please refer to Federal Register 1997; 62 (34): 7857-97. 